\section{Commentary: Pulmonary conduits: A note of optimism in the natural history of dead tissue?}

\author{
Ronald K. Woods, MD, PhD
}

Based on an incredibly large cohort of patients, Marathe and colleagues $^{1}$ report that pulmonary homografts, compared with bovine jugular vein conduits, offer clinically relevant superior freedom from reintervention and structural valve deterioration when the conduit diameter at implantation is $>15 \mathrm{~mm}$. This is a new, interesting finding that we should not ignore, and at the same time, place in appropriate context. In a 2015 report (also large cohort), Sandica and colleagues $^{2}$ concluded just the opposite for patients younger than age 25 years. Patel and colleagues, ${ }^{3}$ in a cohort of 231 bovine jugular implants in the size 16 to $22 \mathrm{~mm}$ range, reported 5- and 10-year freedom from replacement that appears to be superior to those of Marathe and colleagues ${ }^{1}$ (199 implants) based on freedom from replacement. Marathe and colleagues ${ }^{1}$ report reintervention (which will be higher); however, I doubt that the low numbers of catheter-based reinterventions in the series offered by Patel and colleagues ${ }^{3}$ account for these findings. Oh, and by the way, all the aforementioned reports support what we already know about endocarditis: Very low for pulmonary homografts and $7 \%$ to $10 \%$ for bovine jugular conduits.

This report met the standards and scrutiny of expert statistical review of the Journal, so I tread lightly. But I am a bit intrigued by the numbers. To reduce the influence of various biases inherent to such a study, the authors included several covariates, including size of the conduit. But in the propensity score matched analysis, the only variable related to size was whether or not the diameter was $>15 \mathrm{~mm}$. The

\footnotetext{
From the Division of Pediatric Cardiothoracic Surgery, Herma Heart Institute, Children's Wisconsin, Milwaukee, Wis; and Department of Surgery, Medical College of Wisconsin, Milwaukee, Wis.

Disclosures: Dr Woods is cofounder of OperVu Inc.

The Journal policy requires editors and reviewers to disclose conflicts of interest and to decline handling or reviewing manuscripts for which they may have a conflict of interest. The editors and reviewers of this article have no conflicts of interest.

Received for publication Dec 6, 2021; revisions received Dec 6, 2021; accepted for publication Dec 7, 2021; available ahead of print Dec 11, 2021.

Address for reprints: Ronald K. Woods, MD, PhD, Department of Surgery, Medical College of Wisconsin, 9000 W Wisconsin Ave, MS B 730, Milwaukee, WI 53226 (E-mail: rwoods@chw.org).

J Thorac Cardiovasc Surg 2022;164:763-4

$0022-5223 / \$ 36.00$

Copyright (c) 2021 by The American Association for Thoracic Surgery

https://doi.org/10.1016/j.jtcvs.2021.12.015
}

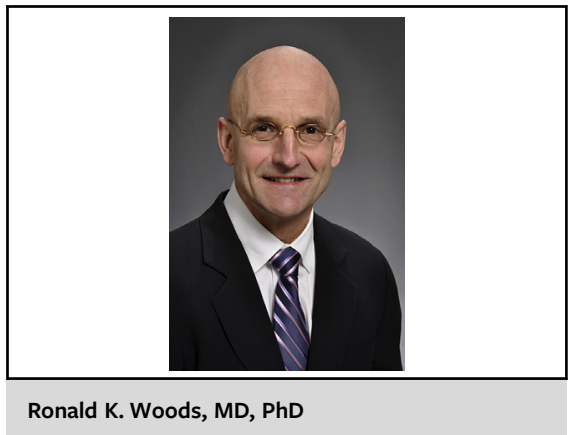

CENTRAL MESSAGE

For larger pulmonary conduits, pulmonary homografts may offer greater freedom from reintervention and/or structural valve deterioration than bovine jugular conduits.

median diameter for bovine conduits was $18 \mathrm{~mm}$ (interquartile range, $14-20 \mathrm{~mm} ; 22 \mathrm{~mm}$ is largest commercially available); whereas, for pulmonary homografts the median diameter was $23 \mathrm{~mm}$ (interquartile range, 20-25 mm). From my admittedly nonexpert data analytic capabilities, lumping all these conduits into a single $>15 \mathrm{~mm}$ group could be a potential source of bias in favor of pulmonary homografts. Even if this were the case, their findings remain interesting and noteworthy.

I do think there may be some validity to their results, but must disclose my current practice and opinion are already in line with what the authors either recommend or imply. More specifically, I typically implant the bovine jugular conduit only in neonates or infants or in patients for whom I expect a need to return for additional surgery during the next 3 to 5 years, and usually only when a suitably sized pulmonary homograft is not available or when additional conduit length is needed for the reconstruction. For older children, the concern about endocarditis alone is sufficient to dissuade me. We must acknowledge the ongoing utility of the bovine conduit in specific circumstances. Similar to others, I advocate for a better conduit, but we should remain grateful that we have both types of conduits available. Because they are all dead biologic tissue and subject to the natural history of dead tissue, I am amazed they work as well as they do. 


\section{References}

1. Marathe SP, Hussein N, Wallace FRO, Bell D, Yong M, Betts KS. Comparison of homografts and bovine jugular vein conduits in the pulmonary position in patients $<20$ years of age. J Thorac Cardiovasc Surg. 2022;164:752-62.e8.

2. Sandica E, Boethig D, Blanz U, Goerg R, Andreas Hass N, Thorsten Laser K. Bovine jugular veins versus homografts in the pulmonary position: an analysis across two centers and 711 patients-conventional comparisons and time status graphs as a new approach. Thorac Cardiovasc Surg. 2016; 64:25-35.

3. Patel PM, Tan C, Srivastava N, Herrmann JL, Rodefeld MD, Turrentine MW. Bovine jugular vein conduit: a mid-to long-term institutional review. World J Pediatr Congenit Heart Surg. 2018;9:489-95. 